\title{
A quick and reliable method for genome- wide host factor screening of Saccharomyces cerevisiae killer toxins
}

\author{
Elena Serviené $\dot{1}^{1,2}$, \\ Juliana Lukša ${ }^{2}$, \\ Iglè Vepštaitė-Monstavičè ${ }^{2}$, \\ Jaunius Urbonavičius ${ }^{1,3^{*}}$ \\ ${ }^{1}$ Department of Chemistry and Bioengineering, \\ Vilnius Gediminas Technical University, \\ Sauletekio Ave. 11, LT-10222 \\ Vilnius, Lithuania \\ ${ }^{2}$ Laboratory of Genetics, \\ Institute of Botany, Nature Research Centre, \\ Akademijos St. 2, LT-08412 \\ Vilnius, Lithuania \\ ${ }^{3}$ Department of Molecular \\ Microbiology and Biotechnology, \\ Institute of Biochemistry, Vilnius University, \\ Sauletekio Ave. 7, LT-10222, \\ Vilnius, Lithuania
}

\begin{abstract}
Numerous yeasts produce toxic compounds to fight the competitors. Such compounds include small molecules (like antibiotics), antibiotic peptides, and also larger proteins, including killer toxins. Their ability to affect the cell depends on the host factors modulating the killing activity. Here we describe a robotics-based method to advance the genome-wide screening for the host factors affecting sensitivity of budding yeast to the killer toxins using the K2 system as the model. We demonstrate that arraying the mutant library on the agar plates containing the K2 killer toxinproducing strain and/or purified toxin ("survival" assay) increases the sensitivity and speed of the screen and decreases the costs compared to the traditional "killer" assay. We show the applicability of a new screening method of searching for the host factors using a killer strain isolated from agricultural plant environment. In addition, the "survival" assay allows identification of previously undetected factors that could be the "missing links" in the pathways of toxininduced cellular responses.
\end{abstract}

Keywords: Saccharomyces cerevisiae, K2 toxin, genomewide screen, pinning robot

\section{INTRODUCTION}

A large variety of yeast secrete different classes of compounds aimed at preventing the growth of the competitors (Meinhardt, Klassen, 2009). These compounds include small molecules, antibiotic peptides, and even proteins. Killer toxins are the fungicidal proteins produced by different genera like Williopsis, Pichia, Kluyveromyces, and Saccharomyces. Nowadays, a particular interest in yeast killer strains and corresponding secreted tox-

*Corresponding author. E-mail: Jaunius.Urbonavicius@vgtu.lt ins has emerged. Both of those have found application in industry (food protection from spoiling, wine production), agriculture (phytopathogen control), or medicine (creation of new generation vaccines and antibiotics, development of antifungal immunotherapies) (Goretti et al., 2009; Rodriguez-Cousino et al., 2011; Hatoum et al., 2012; Magliani et al., 2012; Maqueda et al., 2012). It is only rather recently that significant progress in the identification of killing principles and strategies, mechanisms of immunity, and approaches for the practical application of such proteins has been made. 
Several genome-wide screens searching for the factors altering sensitivity to killer proteins have been performed. Irrespective of the origin of the toxin, Saccharomyces cerevisiae libraries of non-essential gene mutants are usually used. They are sometimes complemented by a set of conditional alleles of essential genes. In this way genome-wide screens involving the K1 and K28 killer toxins from S. cerevisiae, HM-1 toxin from Williopsis saturnus, $\gamma$-toxin from Kluyveromyces lactis, and also the killer peptide derived from Pichia anomala were carried out (Pagé et al., 2003; Conti et al., 2008; Huang et al., 2008; Carroll et al., 2009; Miyamoto et al., 2011).

Performing the experiments with the $W$. saturnus, $K$. lactis, and P. anomala toxins, colonies from the $S$. cerevisiae libraries were manually arrayed on the agar plates, and the growth of mutants was further tested either in solid or liquid media (Conti et al., 2008; Huang et al., 2008; Miyamoto et al., 2011). In the case of K1 and K28 toxins, a different approach was used. Here each mutant strain was incorporated into a separate agar plate and the resistance to the toxins was scored by spotting on top the purified toxin or the toxin-producing strain with subsequent measuring of the inhibition zones ("killer" assay) (Pagé et al., 2003; Carroll et al., 2009).

In this work we combined two above-mentioned methods and developed both fast and reliable assay to screen for the S. cerevisiae mutants with altered sensitivity to K2 killer toxin. Furthermore, we demonstrated the sensitivity of the robotic system, which allowed us to identify additional mutants missed in the traditional "killer" assay. In addition, the applicability of the "survival" assay for searching for the host factors was demonstrated using $S$. cerevisiae killer toxin $\mathrm{Kz}$ isolated from the agricultural plant environment.

\section{MATERIALS AND METHODS}

\section{Robot-aided screening of the mutants ("sur- vival" assay)}

About 4750 single nonessential gene deletion mutants consisting of BY4741 (MATa his $3 \Delta 1$ leu $\Delta 2$ met $\Delta 0$ ura $\Delta 3$ ) derivatives were arrayed on YPD+G418 agar plates (1\% yeast extract, $2 \%$ peptone, $2 \%$ dextrose, $2 \%$ agar, $200 \mu \mathrm{gL}^{-1}$ G418) in the 96 colony format. The strains to be tested were then transferred either onto YPD agar plates (Plus Plates, Singer Instruments, Roadwater, UK), or into the liquid YPD medium in 96-well plates (Cellstar, cat. no. 655180, Greiner Bio-one, Germany), $150 \mu \mathrm{L} /$ well, and grown for one day $(18-24 \mathrm{~h})$ at $30^{\circ} \mathrm{C}$. The agar YPD-grown cells were then deposed onto plates containing $40 \mathrm{~mL}$ of MB-agar medium $(0.5 \%$ yeast extract, $0.5 \%$ peptone, $2 \%$ dextrose, adjusted to $\mathrm{pH} 4$ with $75 \mathrm{mM}$ phosphate-citrate buffer supplemented with $0.002 \%$ methylene blue dye) mixed with either $2 \times 10^{5}$ or $2 \times 10^{6}$ cells of overnight pre-grown $\mathrm{K} 2$ toxin-producing strain M437 (wt, HM/HM [kilK2]) (Gulbiniene et al., 2004). A similar strategy was used for screening of $S$. cerevisiae $\mathrm{Kz}$ toxin-producing strain isolated from the agricultural environment.

In parallel, liquid YPD-grown cells were transferred onto $\mathrm{MB}$-agar plates containing either $300 \mathrm{U}$ or $600 \mathrm{U}$ (as determined in Gulbiniene et al., 2004) of partially purified K2 toxin (Lebionka et al., 2002). All plates were incubated for two days $(42-48 \mathrm{~h})$ at $25{ }^{\circ} \mathrm{C}$. The size and the colour of the colonies grown on the agar supplemented with M437 cells were evaluated visually, and pictures were taken using a PowerShot SX220 HS digital camera (Canon, Tokyo, Japan). The respective blue (corresponding to increased sensitivity to $\mathrm{K} 2$ toxin) and white (increased resistance) colonies, differing in colour from their neighbours and those in the control plate (no toxin), were selected as candidates for altered sensitivity to K2 toxin. The pictures of colonies grown on the agar plates containing purified $\mathrm{K} 2$ toxin were taken using either a Genosmart transilluminator (VWR International) or a Pathway ${ }^{\mathrm{mm}}$ 435 automated microscope (BD Biosciences, USA). Reduced in size or non-growing on the MB-agar with $300 \mathrm{U}$ of $\mathrm{K} 2$ toxin colonies were selected as hypersensitive mutants, while the colonies growing at $600 \mathrm{U}$ of toxin (no growth for wild-type control) were selected as the resistant strains. 
Verification of the phenotypes of the selected mutants ("killer" assay)

About $2 \times 10^{6}$ cells of respective strain, selected using the "survival" assay, were grown overnight in liquid YPD, mixed with $10 \mathrm{~mL}$ of melted and pre-cooled to $45^{\circ} \mathrm{C} \mathrm{MB}$-agar, and then poured into a standard 50-mm-diameter plastic Petri dish. Afterwards the inhibition zones were established either by (1) patching on the top of the agar the K2 toxin-producing strain M437, (2) deposing $5 \mu \mathrm{L}(0.5 \mathrm{U})$ of purified $\mathrm{K} 2$ toxin, or (3) filling the $10-\mathrm{mm}$-wide cut into the agar wells with $100 \mu \mathrm{L}(10 \mathrm{U})$ of $\mathrm{K} 2$ ("well" assay). The plates were incubated for two days at $25^{\circ} \mathrm{C}$, and non-growth zones of mutants were established. Identical approaches of the "killer" assay were used for the verification of deletion mutants detected in the "survival" assay and involved in resistance formation to $\mathrm{Kz}$ toxin. The summary of the screening procedure in both "killer" and "survival" assays is represented in Fig. 1.

\section{RESULTS AND DISCUSSION}

\section{Screening procedure}

Dominating in the vineyard-winery ecosystems, S. cerevisiae K2 killer yeasts produce toxin that is lethal to sensitive or other type of the killer toxins producing yeast strains (Gulbiniene et al., 2004). The ability to kill or to protect from the toxic action depends on the general features of the toxin and is influenced by the cellular self-defence mechanisms (Meinhardt, Klassen, 2009).

In order to identify encoded factors of budding yeast that mediate sensitivity to K2 toxin, we first established the "survival" assay using

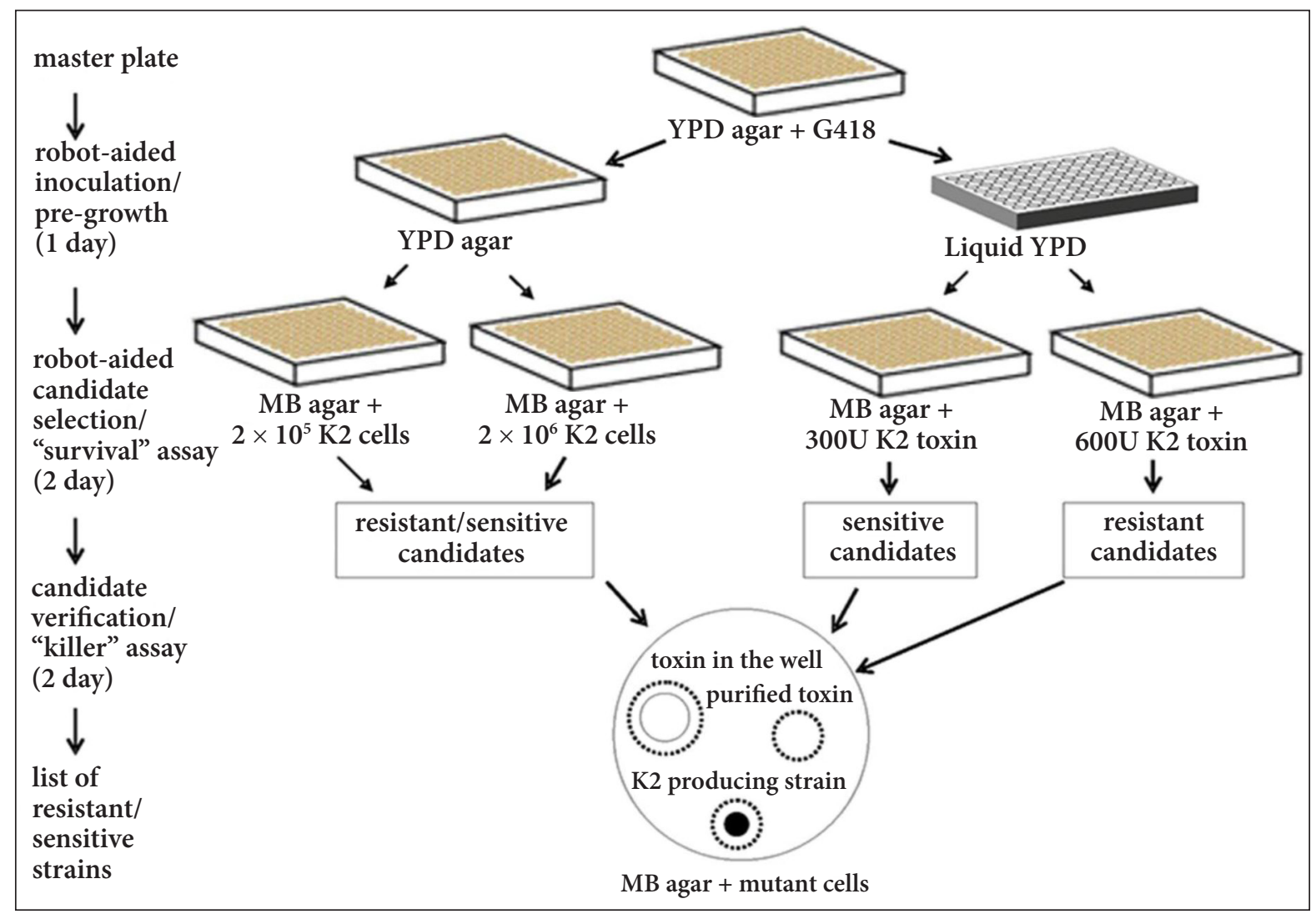

Fig. 1. YPD+G418. The cells were transferred either onto YPD-agar or into YPD liquid and grown overnight. Then the cells from YPD-agar were replicated onto the MB-agar, seeded with an overlay of the K2 toxin producing strain M437; liquid YPD pre-grown cells were transferred onto the MB-agar containing the K2 toxin. Respective resistant and sensitive mutants were selected. Verification of candidates was performed using the "killer" assay by deposing either purified K2 toxin into the agar-cut wells, or spotting either the toxin or K2 toxin-producing strain on top of the agar 
the RoToR pinning robot (Singer Instruments, Roadwater, UK), and then performed the "killer" assay to verify the candidate strains. Figure 2 depicts the principal scheme of the selection procedure, from the robotic screen of the yeast libraries to the verification of candidates and, finally, obtaining the hits.

\section{Selection of the factors affecting $\mathrm{K} 2$ toxin resistance}

The respective blue (corresponding to increased sensitivity to K2 toxin) and white (increased resistance) colonies, differing in colour from their neighbours and those in the control plate (no toxin) (Fig. 3A) were selected as candidates for altered sensitivity to K2 toxin. Reduced in size or non-growing on MB-agar with $300 \mathrm{U}$ of $\mathrm{K} 2$ toxin colonies (compared with the control plate) were selected as hypersensitive mutants (Fig. 3B), while colonies, growing at $600 \mathrm{U}$ of toxin (no growth for wild-type control) were selected as the resistant strains (Fig. 3C). Using such a "survival" assay with the $\mathrm{K} 2$ killer producing strain, we found 311 strains demonstrating marked (big white colonies) resistance and 52 strains demonstrating weak (small whitish colonies) resistance.

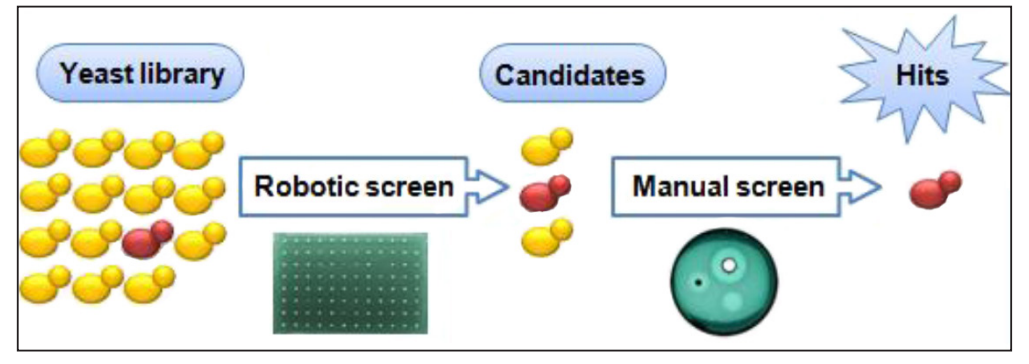

Fig. 2. The principal scheme for the selection of the candidate genes from the yeast mutant libraries

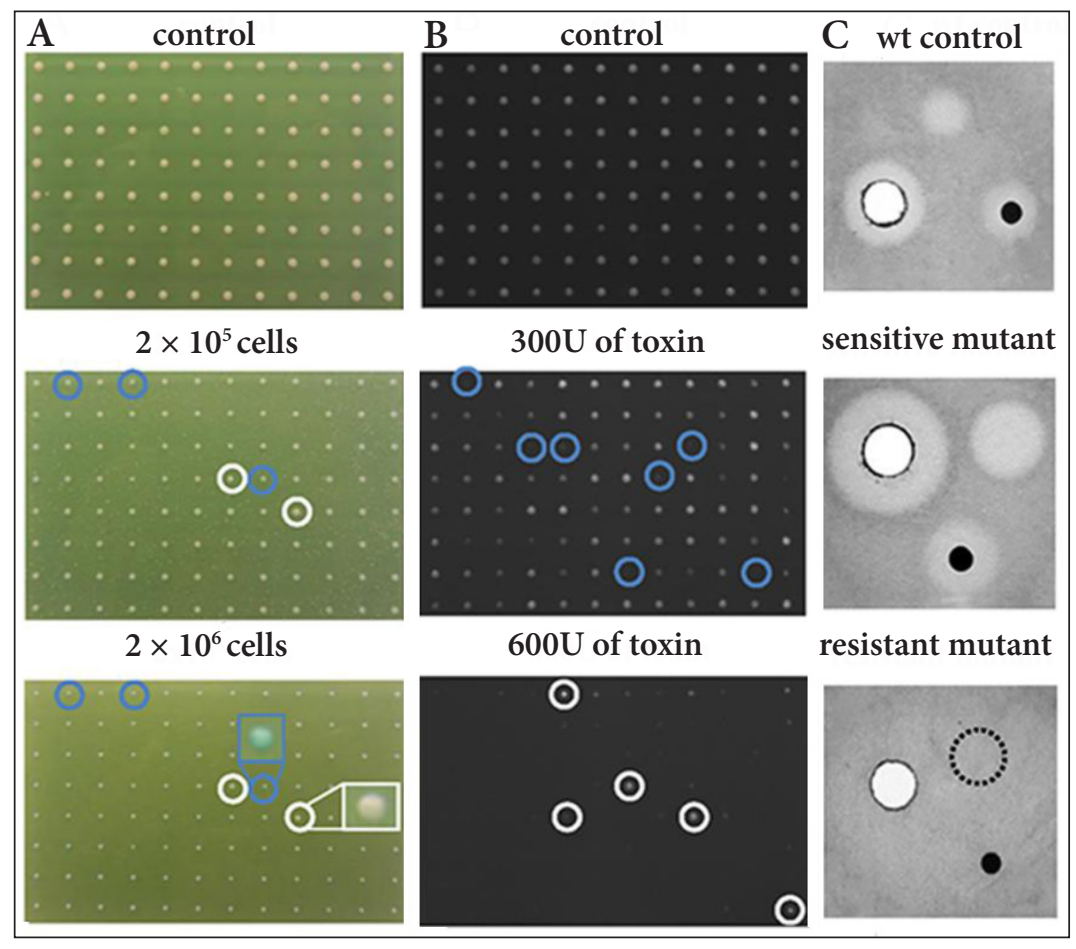

Fig. 3. Selection of S. cerevisiae mutants with altered sensitivity to K2 toxin. (A) Agar plates containing the K2 toxin-producing cells and the arrayed colonies of mutants. Resistant colonies are encircled in white, sensitive colonies - in blue. Images of typical sensitive and resistant colonies are magnified. (B) Agar plates containing purified $\mathrm{K} 2$ toxin inside and the arrayed colonies of mutants on top. The colonies are encircled as above. (C) Examples of the "killer" assay results for the wild type and extremely sensitive and resistant mutants 
At the same time, 209 mutants exhibited marked (deep blue colonies), and 74 ones weak (blue colonies) hypersensitivity. When K2 toxin was used in a similar assay, 232 strains with marked (big colonies), and 61 strains with weak (small colonies) resistant phenotype were selected. Also, we discovered 287 strains with marked (traces of/no colonies) and 38 ones with weak (smaller than the wild-type colonies) hypersensitive phenotypes. These data are summarized in the "survival" assay part of Fig. 4. Some of the mutant strains show phenotypic differences from wt cells when $\mathrm{K} 2$ producing strain but not $\mathrm{K} 2$ toxin was used, and vice versa. For some other mutants such phenotypes were observed in both cases. In total, about 850 strains demonstrating reliable growth rate/colour differences from the parental strain in at least one of two approaches of the initial screening procedure were further tested using the "killer" assay.

\section{Verification of K2 killer phenotypes using the "killer" assay}

Verification and quantitative evaluation of $\mathrm{K} 2$ killer resistance phenotypes of the candidates se- lected from the "survival" assay was performed using 3 approaches ("killer" assays). Figure 3C shows the examples of the extremely sensitive and resistant mutants and corresponding wildtype control. Using this method, a list of 332 mutants, phenotypically different from the wild type strain BY4741, was established. About twothirds of the selected mutants demonstrated either marked $\mathrm{K} 2$ resistance $(<2 \mathrm{~mm}$ radius of non-growth zones in the "well" assay) or sensitivity ( $>3.5 \mathrm{~mm}$ radius of non-growth zones). The remaining one-third of the mutants showed weak resistance (2-2.5 mm of non-growth zones) or sensitivity (3-3.5 mm of non-growth zones), whereas the wild type strain demonstrated nongrowth zones of about $2.5-3 \mathrm{~mm}$. These data are summarized in the "killer" assay part of Fig. 4. The list and analysis of the aforesaid 332 mutants has been published (Servienè et al., 2012).

Surprisingly, some 520 of 850 candidates discovered in the "survival" assay were missing in the "killer" assay. This phenomenon can be attributed to the use of robotics resulting in higher sensitivity, and the variation in the growth rates of different mutants.

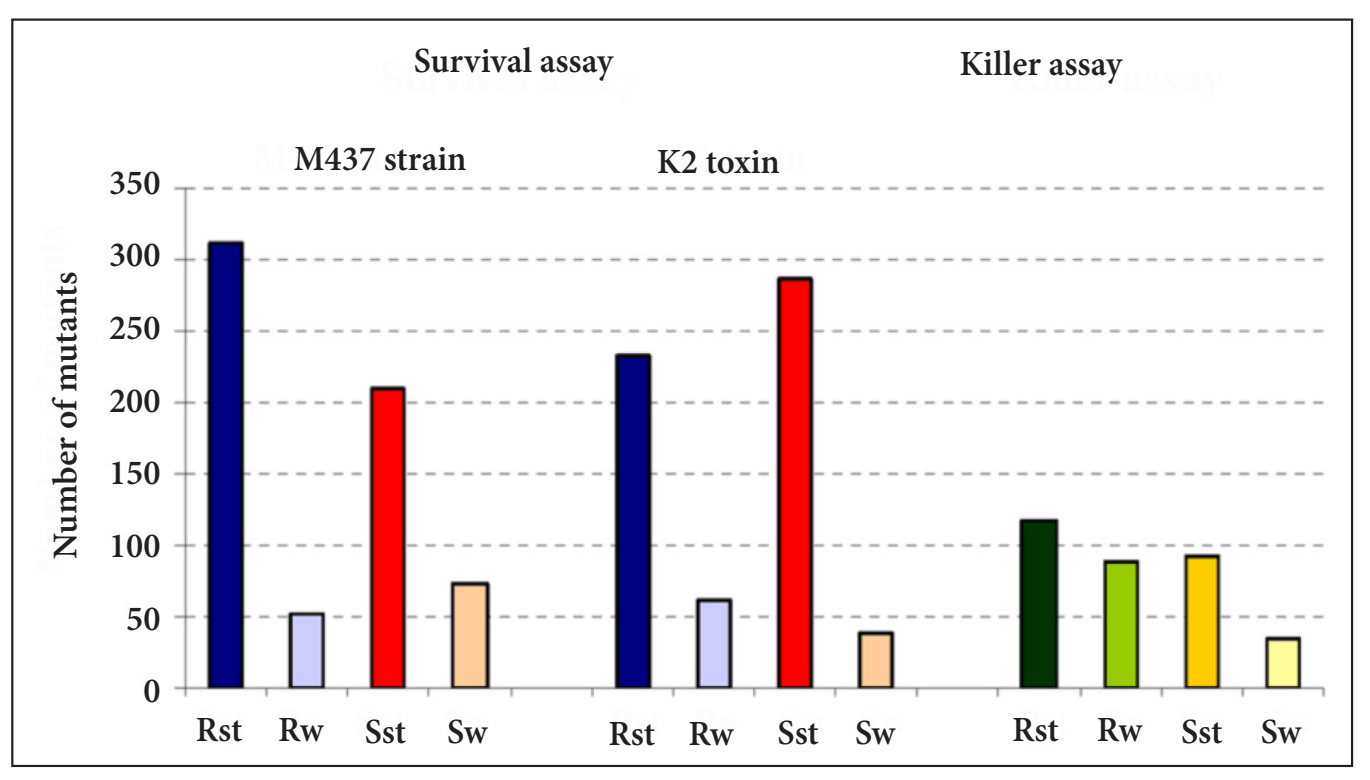

Fig. 4. Distribution of the resistant and hypersensitive mutants selected by the "survival" and "killer" assays. Deep blue denotes strong resistant (Rst), whereas light blue - weak resistant (Rw) mutants obtained using the "survival" assay. Red denotes strong (Sst), and pink - weak (Sw) hypersensitive mutants selected by the same approach. Strong resistant hits (Rst) from the "killer" assay are marked in deep green, while the weak ones (Rw) are marked in light green. The sensitive hits (Sst and Sw) from the same assay are marked in different shades of yellow, respectively 


\section{Advantages of the use of the pinning robot}

Here we demonstrate the advantages of the use of the pinning robot for the selection of mutants with altered sensitivity to the K2 killer toxin. In comparison to the K1 and K28 killer toxin genome-wide screens where only the "killer" assays were used, fast and sensitive "survival" assay-based screen using either K2 toxin producing strain or the purified K2 toxin was first performed. We see several advantages of this method compared to traditional inhibition zone approach. First, it reduces the initial number of the candidates to be verified by the traditional "lysis zone" method about 5.5x (approx. 850 strains instead of 4750), thereby replacing tedious handwork and reducing the cost of the growth medium used as well as increasing reproducibility of the colony arraying. Secondly, the use of both the K2-toxin producing strain and the purified K2 toxin in parallel increases the sensitivity of screening and allows selection of the candidates possessing even a weak phenotype. We found that $85 \%$ of mutants demonstrating a strong phenotype, confirmed by the "killer" as- say, could be picked using only a K2 toxin-based "survival" assay (Serviene et al., 2012). This demonstrates that in the majority of cases, such strategy of screening could be used for the selection of marked candidates. In contrary, for the detection of weak phenotype possessing candidates, both "survival" assay approaches should be used. Seventy-five percent of weak mutants confirmed by the "killer" assay demonstrated more pronounced phenotype in the K2-producing strainbased "survival" assay than the one using the K2 toxin (Servienè et al., 2012). The former assay is especially useful for testing of slowly growing mutants with altered physiology because of mild conditions achieved by slow but continuous action of the toxin produced by the killer cells. In addition, we demonstrated potential of survival assay-based screen for searching of host factors modulating sensitivity to S. cerevisiae killer toxin $\mathrm{Kz}$ isolated from agricultural plant environment. When such killer toxin producing strain was used as a selection agent, colonies differing from their neighbours in colour and those in the control plate (no toxin) were distinguished (Fig. 5).

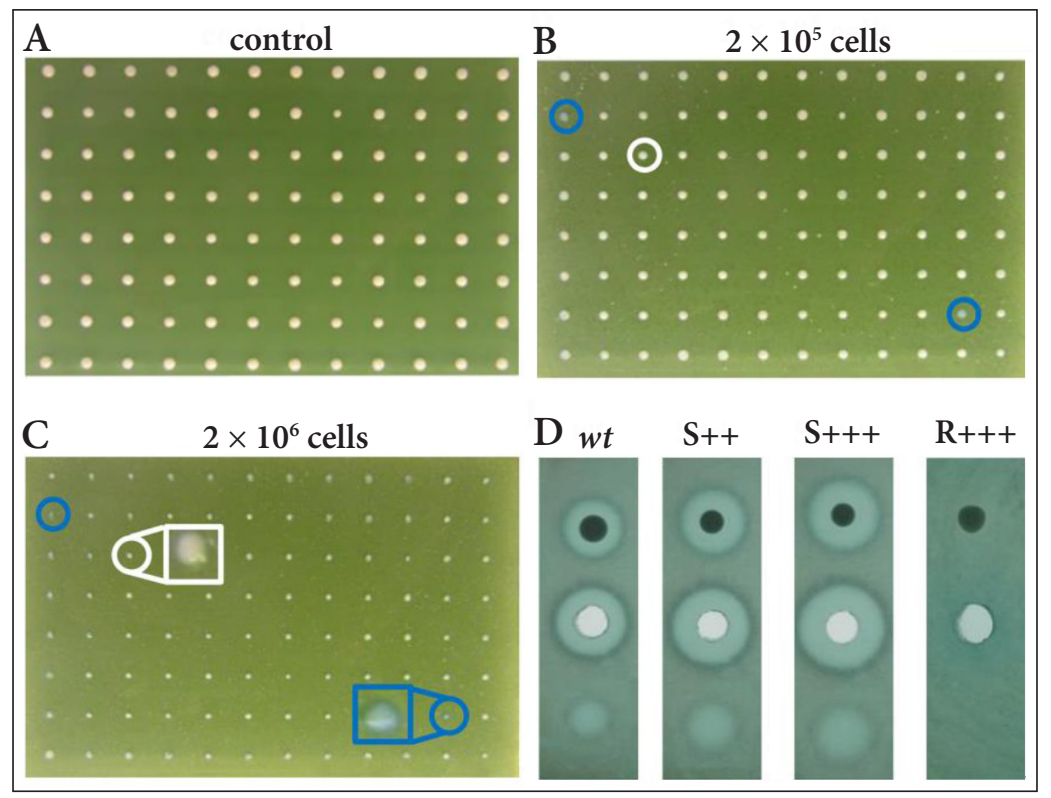

Fig. 5. Applicability of the "survival" assay for screening of the S. cerevisiae mutants with altered sensitivity to $\mathrm{Kz}$ toxin. (A) Nonessential gene deletion mutants deposited on MB-agar plates. $(\mathrm{B}, \mathrm{C})$ Agar plates containing the $\mathrm{Kz}$ toxin-producing cells $\left(2 \times 10^{5}\right.$ and $2 \times 10^{6}$ cells/plate $)$ and the arrayed colonies of mutants. Resistant colonies are encircled in white, sensitive colonies - in blue (images of typical sensitive and resistant colonies are magnified). (D) Detected in the "survival" assay, sensitive ( $\mathrm{S}++$, $\mathrm{S}+++)$ and resistant $(\mathrm{R}+++)$ mutants were verified by the "killer" assay 
The respective blue (corresponding to increased sensitivity to $\mathrm{Kz}$ toxin) and white (increased resistance) colonies were verified by the "killer" assay (Fig. 5D). We believe that the possibility to alternate harsh and mild test conditions could also be used for screening of the yeast essential gene libraries (e. g., yTHC, DAmP, Ts/Cs). Thirdly, the introduction of several independent testing methods (identification of resistant and hypersensitive strains by the use of the pinning robot and verification of the phenotype by applying the "killer" assay) instead of repeating the same experiment significantly increases the reliability of genome-wide screening. Even if the pinning robot is not available, the screening scheme could be used with affordable manual pinning tools.

\section{CONCLUSIONS}

In this work we developed a new method to screen the yeast gene deletion library for factors affecting toxin susceptibility and demonstrated its advantages. We showed that the majority of mutants could be selected using only the pinning robot (the "survival" assay). In addition, this method allows identification of mutants not detected by the traditional "killer" assay. Those factors could be "missing" links in the pathways of toxin-induced cellular responses that are currently under investigation.

\section{ACKNOWLEDGEMENTS}

The authors thank Charlie Boone and Nydia van Dyk, University of Toronto, Canada, for providing their yeast strain collection.

Received 26 August 2016

Accepted 20 October 2016

\section{References}

1. Carroll SY, Stirling PC, Stimpson HEM, Gießelmann E, Schmitt MJ, Drubin DG. A yeast killer toxin screen provides insights into $\mathrm{A} / \mathrm{B}$ toxin entry, trafficking and killing mechanisms. Dev Cell. 2009; 17: 552-60.
2. Conti S, Magliani W, Giovati L, Libri I, Maffei DL, Salati A, Polonelli L. Screening of a Saccharomyces cerevisiae nonessential gene deletion collection for altered susceptibility to a killer peptide. New Microbiol. 2008; 31: 143-5.

3. Goretti M, Turchetti B, Buratta M, Branda E, Corazzi L, Vaughan-Martini A, Buzzini P. In vitro antimycotic activity of a Williopsis saturnus killer protein against food spoilage yeasts. Int J Food Microbiol. 2009; 131: 178-82.

4. Gulbiniene G, Kondratiene L, Jokantaite T, Serviene E, Melvydas V, Petkuniene G. Occurrence of killer yeast strains in fruit and berry wine yeast populations. Food Technol Biotechnol. 2004; 42: 159-63.

5. Hatoum R, Labrie S, Fliss I. Antimicrobial and probiotic properties of yeast: from fundamentals to novel applications. Front Microbiol. 2012; 19: 421.

6. Huang B, Lu J, Byström AS. A genome-wide screen identifies genes required for formation of the wobble nucleoside 5-methoxycarbonylmethyl-2-thiouridine in Saccharomyces cerevisiae. RNA. 2008; 14: 2183-94.

7. Lebionka A, Servienė E, Melvydas V. Isolation and purification of yeast Saccharomyces cerevisiae K2 killer toxin. Biologija. 2002; 4: 7-9.

8. Magliani W, Conti S, Giovati L, Zanello PP, Sperinde M, Ciociola T, Polonelli L. Antibody peptide based antifungal immunotherapy. Front Microbiol. 2012; 3: 1-9.

9. Maqueda M, Zamora E, Alvarez M, Ramirez M. Characterization, ecological distribution and population dynamics of Saccharomyces sensu stricto killer yeasts in the spontaneous grape must fermentations of southwestern Spain. Appl Envir Microbiol. 2012; 78: 735-43.

10. Meinhardt F, Klassen, F. Yeast killer toxins: fundamentals and applications. In: Anke T, Weber D, editors. The Mycota XV, Physiology and Genetics. 1st edition. Springer, Berlin, Heidelberg; 2009, p. 107-30.

11. Miyamoto M, Furuichi Y, Komiyama T. Genome-wide screen of Saccharomyces cerevisiae for killer toxin HM-1 resistance. Yeast. 2011; 28: $27-41$. 
12. Pagé N, Gérard-Vincent $M$, Ménard P, Beaulieu M, Azuma M, Dijkgraaf GJP, Li H, Marcoux J, Nguyen T, Dowse T, Sdicu AM, Bussey H. A Saccharomyces cerevisiae genomewide mutant screen for altered sensitivity to K1 killer toxin. Genetics. 2003; 163: 875-94.

13. Rodriguez-Cousino N, Maqueda M, Ambrona J, Zamora J, Esteban R, Ramirez M. A new wine Saccharomyces cerevisiae killer toxin (Klus), encoded by a double-stranded RNA virus, with broad antifungal activity is evolutionarily related to a chromosomal host gene. Appl Environ Microbiol. 2011; 77: 1822-32.

14. Servienė E, Lukša J, Orentaitė I, Lafontaine DLJ, Urbonavičius J. Screening the budding yeast genome reveals unique factors affecting K2 toxin susceptibility. Plos One. 2012; 7: e50779.
Elena Servienė, Juliana Lukša, Iglè Vepštaitè-

Monstavičè, Jaunius Urbonavičius

\section{GREITAS IR PATIKIMAS ŠEIMININKO VEIKSNIŲ, MODULIUOJANČIŲ MIELIŲ ŽUDANČIŲ TOKSINŲ POVEIKI, ATRANKOS METODAS}

\section{Santrauka}

Daugelis mielių rūšių gamina toksinus, skirtus kovai su konkurentais. Tokios medžiagos gali būti mažos molekulès (antibiotikai), peptidai ir didesni baltymai - žudantys toksinai. Jų poveikis ląstelei priklauso nuo šeimininko veiksnių, moduliuojančių žudymo lygị. Mes aprašème roboto panaudojimu pagrịstą metodą, pagerinantị šeimininko veiksnių atranką iš $S$. cerevisiae mielių genomo, kai modeliu buvo pasirinktas K2 toksinas. Nustatyta, kad kamienų iš mielių mutantų bibliotekos auginimas ant agaro lèkštelių su K2 toksiną išskiriančiu kamienu ir / arba išgrynintu toksinu („,išgyvenimo“ metodas) padidina atrankos greitị ir jautrumą bei sumažina savikainą, palyginti su tradiciniu „žudymo“ metodu. Pademonstruotas naujo patikros metodo pritaikymas šeimininko koduojamų veiksnių paieškai naudojant iš žemès ūkio augalų aplinkos išskirtą žudantį mielių kamieną. „Išgyvenimo“ metodas taip pat leidžia nustatyti anksčiau neišskirtus veiksnius, kurie gali būti toksino indukuoto ląstelès atsako "trūkstamos grandys“.

Raktažodžiai: Saccharomyces cerevisiae, K2 toksinas, atranka iš genomo, kolonijas pernešantis robotas 